\title{
ENERGY MANAGEMENT OF BUILDINGS THROUGH SUSTAINABLE DESIGN
}

\author{
Harsha D. Bajpai \\ Pillai HOC College of Engineering and Technology, Rasayani, Maharashtra, India \\ Prof. Dr. Tejaswini D. Nalamutt \\ Pillai HOC College of Engineering and Technology, Rasayani, Maharashtra, India
}

\begin{abstract}
Urbanization is gradually becoming a worldwide phenomenon since there is a colossal growth in population around the world. There is an emergent demand of housing around the world and hence construction sector is the booming sector all over the world. This accounts for extreme energy consumption and leading to GHG emissions which contribute to phenomenon of global warming. $\mathrm{CO}_{2}$ is the major gas contributing to GHG emissions. Concrete is the vital building material used in construction. The production of concrete is responsible for emission of $\mathrm{CO}_{2}$ gas. Thus, main aim of energy management of buildings is to propose a sustainable approach in conventional design method which can be introduced during conceptual design stage. This paper enumerates the quantification of the $\mathrm{CO}_{2}$ emission of construction material especially concrete. All construction materials endure through various stages right from raw material extraction, transportation, manufacturing till demolition and waste processing. These stages are called system boundary. The system boundary for present study is manufacturing of concrete which is responsible for emission of $\mathrm{CO}_{2}$ gas. Manufacturing of concrete requires energy consumption in many ways.Power sector in the form of electricity is one of the pathways of energy consumption responsible for $\mathrm{CO}_{2}$ emission. The study involves comparative analysis and design of $G+4 R C C$ building with structural components especially slab and columns as variable parameters. Based on the final design, the quantification of $\mathrm{CO}_{2}$ emission for concrete is accomplished. Available data of energy consumption required for manufacturing process of concrete and integration of emission factor with energy consumption leads to quantification of $\mathrm{CO}_{2}$ emission. The conclusion demonstrate that with variation in design of structural components, a considerable amount of quantity of $\mathrm{CO}_{2}$ emission can be controlled, rather than concentrating on design and analysis of low carbon material, which requires lot of time and cost.
\end{abstract}

Key words: Carbon dioxide $\left(\mathrm{CO}_{2}\right)$, Greenhouse Gas (GHG), Reinforced Cement Concrete (RCC), System Boundary, and Energy Consumption.

Cite this Article: Harsha D. Bajpai and Dr. Tejaswini D. Nalamutt, Energy Management of Buildings Through Sustainable Design, International Journal of Advanced Research in Engineering and Technology, 10 (3), 2019, pp 184-193.

http://iaeme.com/Home/issue/IJARET?Volume=10\&Issue $=3$ 


\section{INTRODUCTION}

Use of global energy is the major sphere in today's scenario. It is directly related to emission of greenhouse gases (GHG) in atmosphere. Sector which is majorly responsible for GHG emissions to annual global emissions leading to global warming is the construction sector. Construction sector is one of the most important sectors. The construction industry not only helps in meeting the housing demand, but provides employment on enormous scale. It has major impact on GDP of country, but need always comes with a challenge. The boom in construction sector is having impact on environmental condition. Construction industry contributes part in global warming due to greenhouse gas emission The global warming is basically the slow heating up of lower atmosphere of earth due to increase in intensity of greenhouse gases, especially CO2 (Spencer 2007). Life on earth will be in danger if there is excess of CO2 emission which will result in the earth's temperature to rise According to United Nations Environment programme, the building sector is responsible for $40 \%$ of the global energy consumption and one third of the GHG emissions. In future, growth in population will lead to rapid growth in building sector which will lead to increase in $\mathrm{CO} 2$ emissions thus effecting global warming. Electricity is one form of energy which is used in construction industry accounting for more than $42 \%$ of fuel emission worldwide alone (IEA2016). Thus, energy management becomes an important aspect for building sector considering power sector as one of the driving factor of $\mathrm{CO} 2$ emission. One of the reasons for $\mathrm{CO} 2$ emission in building sector is manufacturing process and transportation of various construction materials, consequences of subsequence use of energy in form of electricity. Thus, from building design point of view, structural engineers and architects should go for energy management through sustainable design. This can be done by including strategies during early design stage which includes bringing down the $\mathrm{CO} 2$ emission due to energy consumption.

This study mainly focuses on energy management of buildings through sustainable approach by mainly concentrating on driving factors of $\mathrm{CO} 2$ emission of construction material especially concrete based on conventional design method.

Based on the above results obtained, comparative study of the $\mathrm{CO} 2$ emission for conventional design method is performed This study will further help the concern designers and policy makers in rearranging the strategies of conceptual design phase of building project for quantification of $\mathrm{CO} 2$ emission of concrete material. This will help in reducing negative impact of building industry on environment.

\subsection{CO2 emission in Power Sector}

Energy utilization for obtaining, fabricating, conveying, assembling, substitution, dismantlement and retrofitting of construction materials results in $\mathrm{CO}_{2}$ emissions. $\mathrm{CO}_{2}$ accounts for about 76 percent of total greenhouse gas emissions (IPCC (2014)), as shown in Figure 1. India is third largest country amongst world's 20 largest carbon emitting countries as shown in Figure 2.

Emission of $\mathrm{CO}_{2}$ can take place from areas which are divided into two parts

1) Direct emissions: Here emission takes place during production

2) Indirect emissions: Result from consumption of energy in the form of electricity.

Other greenhouse gases are methane and nitrous oxide, articulated as $\mathrm{CO} 2 \mathrm{e}$ or $\mathrm{CO} 2$ equivalent, which is an evaluation way to convey the emissions from the above-mentioned gases influenced by their global warming potential. The Global Warming Potential of a structure (GWP, expressed in $\mathrm{kgCO} 2 \mathrm{e} / \mathrm{m}^{2}$ when normalized by floor area) can be calculated by multiplying these two key variables, as illustrated in Equation no. 1. (Source Catherine De Wolf, 2017). 


$$
\mathrm{GWP}=\mathrm{SMQi} \times \mathrm{ECCi} \quad \text { Equation no. } 1
$$

Where: $i$ is a particular material in building structure

GWP Global Warming Potential $\left(\mathrm{kgCO} 2 \mathrm{e} / \mathrm{m}^{2}\right)$

SMQi Structural Material Quantities $\left(\mathrm{kgm} / \mathrm{m}^{2}\right)$

ECCi Embodied Carbon Coefficients $(\mathrm{kgCO} 2 \mathrm{e} / \mathrm{kg})$

The scope of $\mathrm{CO} 2$ calculation is called the system boundary. Stages of system boundary are as follows: cradle-to-gate, cradle-to-site, and cradle-to-end of construction, cradle-to grave or even cradle-to cradle (EN151515978:2011).

$\mathrm{CO} 2$ emission from power sector i.e. electricity is usually expressed in $\mathrm{kg} \mathrm{CO} 2 / \mathrm{MWh}$, which consumed during manufacturing of construction material.

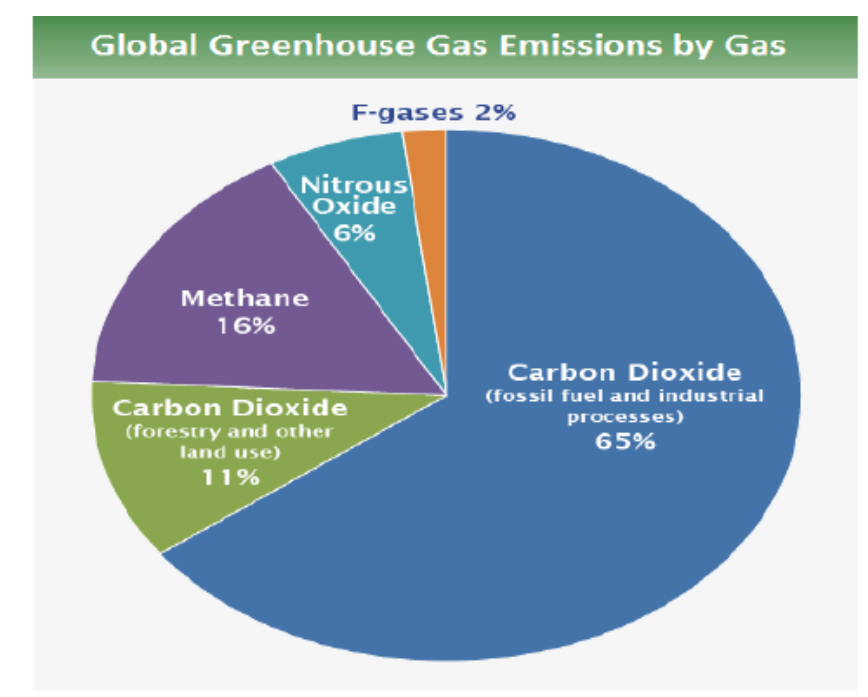

Figure 1 Global Greenhouse gas emission data (Source: IPCC (2014)

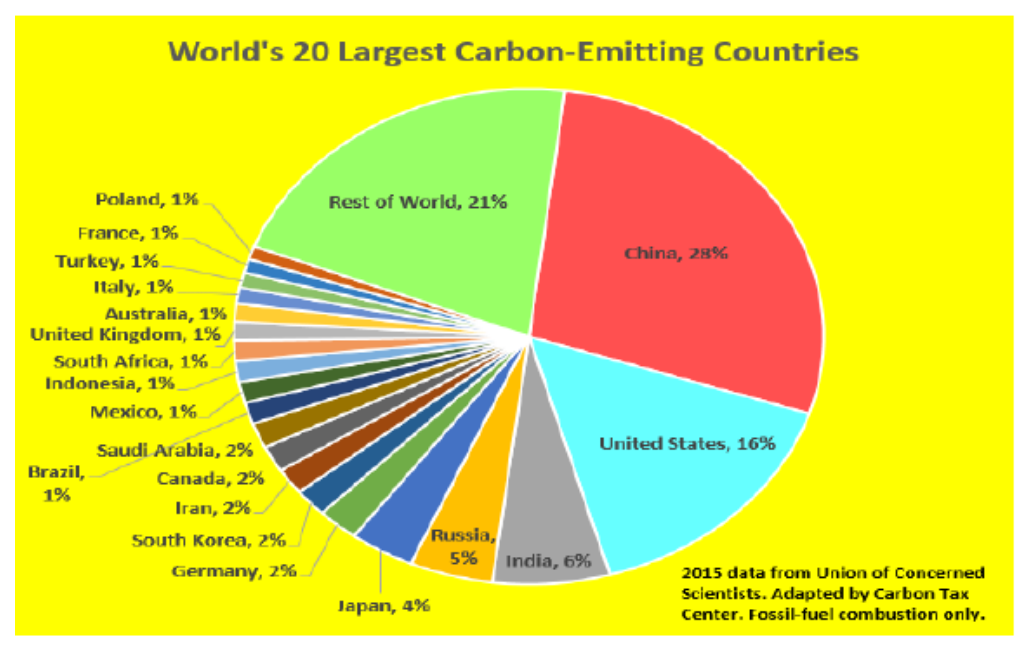

Figure 2 World's 20 largest carbon Emitting Countries

(Source: 2015 Data from Union concerned scientist)

\subsection{System boundary}

The scope of the $\mathrm{CO} 2$ calculation is called the system boundary.

For energy management of buildings through sustainable design, system boundary is requisite. It includes complete life cycle of buildings and products right from the material extraction to 
end-of-life. Segregation of a system (Life cycle stage) under investigation is system boundary as shown in Figure 3. It is necessary to define the system boundary of the analysis to understand which materials and processes need to be considered.

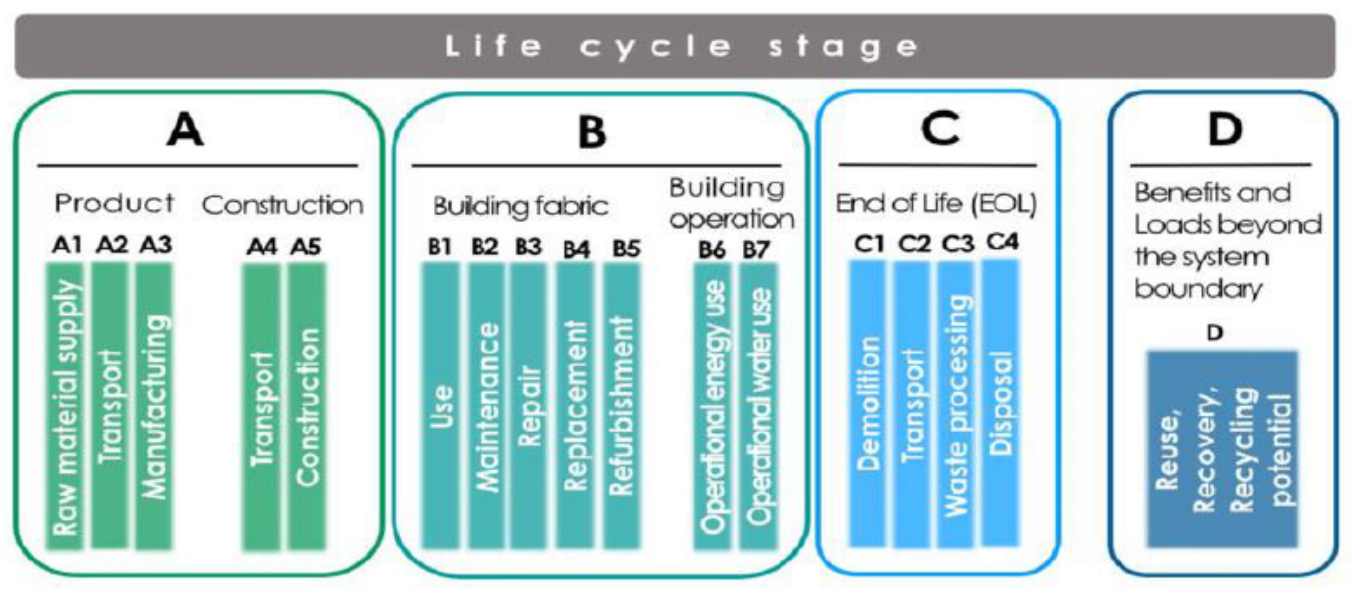

Figure 3 Building life cycle stages

(Source: adapted from EN151515978:2011)

\subsection{Sustainable Design}

Sustainable design endeavour to lessen the adverse impacts on the environment, and the health and comfort of building inhabitants, thereby improving building performance. The elementary objective of sustainability is to reduce depletion of non-renewable resources, abate waste, and create healthy, productive environments. Here sustainable design for energy management is implemented by bringing down the $\mathrm{CO}_{2}$ emission through energy consumption in buildings through analysis and design of RCC structure. This opportunity will not only help to minimize the total cost or total weight of a structure but also to minimize energy consumption and carbon emission.

Sustainable design acts as an associate of smart solution for smart cities.

\section{METHODOLOGY}

Research design includes the comparative analysis of $\mathrm{G}+4$ structure using Staad pro software. Further design of structure is carried out using conventional design method, the result of which can be effectively integrated with different data of energy consumed for the manufacturing of concrete and refining them to produce finished product which results in $\mathrm{CO}_{2}$ emission. The methodology is shown in the form of flow chart in Figure 4.

\subsection{Data collcetion}

In order to estimate the $\mathrm{CO}_{2}$ emission of the building constuction material ,the data collection should be very precise.In this research, data is placed in two broad forms. The first form of data includes design parameters required for the analysis and design of RCC structure. The second form of data is external data. This includes energy consumption during manufacturing of building material.Here the source of data for energy consumed is the RMC plant ,including weighted average emission factor expressed in units $\mathrm{kgCO}_{2} / \mathrm{MWh}$.

\subsection{Data Analysis}

Analysis of the structure is carried out on following design basis assumptions.

Design philosophy for RCC framed structure 
- Lateral force resisting system shall consist mainly of columns. The columns along with the floor slab acting as floor diaphragm (there by acting as tie between columns) shall form the lateral load resisting system.

- The whole structure is idealized in Staad pro software as a space frame and each beam and column in the structure is modelled as a line member element.

- RC Columns and Beams are designed using Limit State Method of design as per IS 456.

- Boundary Conditions: Base of the structure is considered as fixed for superstructure analysis.

- Effects due to non-structural components such as block walls, stairs, parapet walls, glass/stone cladding etc. are accounted appropriately in static loading and lumped mass calculations.

Following are the load combinations used for analysis and design of RCC structure as per codal reference.
i) $1.5 \mathrm{DL}+1.5 \mathrm{LL}$, ii) $1.2 \mathrm{DL}+1.2 \mathrm{LL}+1.2 \mathrm{WL}(+-\mathrm{X})$, iii) 1.2DL+1.2LL+1.2WL $(+-\mathrm{Z})$,
iv) $1.5 \mathrm{DL}+1.5 \mathrm{WL}(+-\mathrm{X})$, v) $1.5 \mathrm{DL}+1.5 \mathrm{WL}(+-\mathrm{Z})$, vi) $0.9 \mathrm{DL}+1.5 \mathrm{WL}(+-\mathrm{X})$,
vii) $0.9 \mathrm{DL}+1.5 \mathrm{WL}(+-\mathrm{Z})$, viii) $1.2 \mathrm{DL}+1.2 \mathrm{LL}+1.2 \mathrm{EL}(+-\mathrm{X})$,
ix) $1.2 \mathrm{DL}+1.2 \mathrm{LL}+1.2 \mathrm{EL}(+-\mathrm{Z}), \mathrm{x}) 1.5 \mathrm{DL}+1.5 \mathrm{EL}(+-\mathrm{X})$
xi) 1.5DL+1.5EL (+-Z), xii) 0.9DL+1.5EL (+-X), xiii) 0.9DL+1.5EL (+-Z),
xiv) $1.5 \mathrm{DL}+1.5 \mathrm{EL}(+-\mathrm{X})$, xv) $1.5 \mathrm{DL}+1.2 \mathrm{EL}(+-\mathrm{Z})$

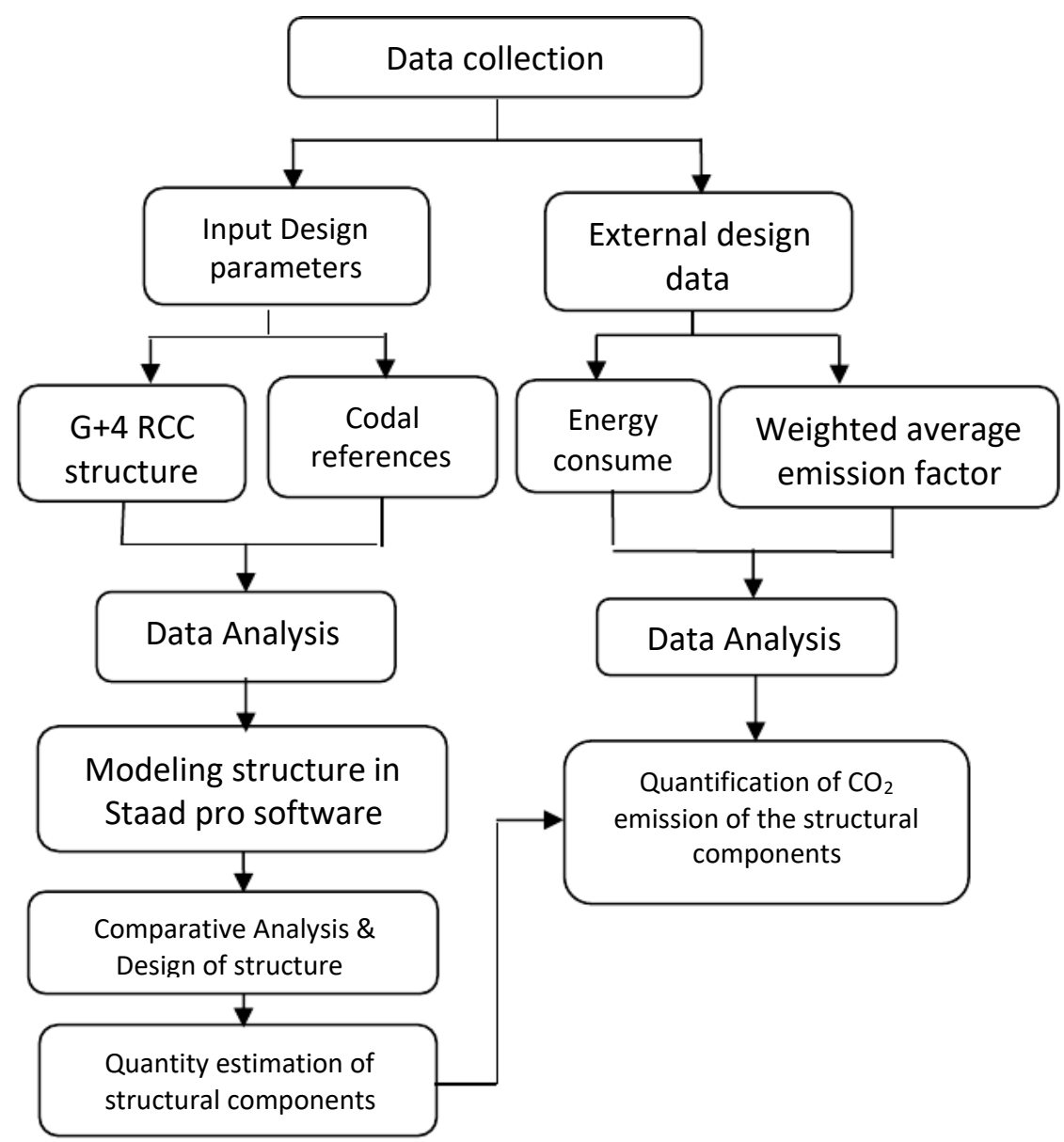

Figure 4 Flow chart illustrating the Quantification of $\mathrm{CO}_{2}$ emission 

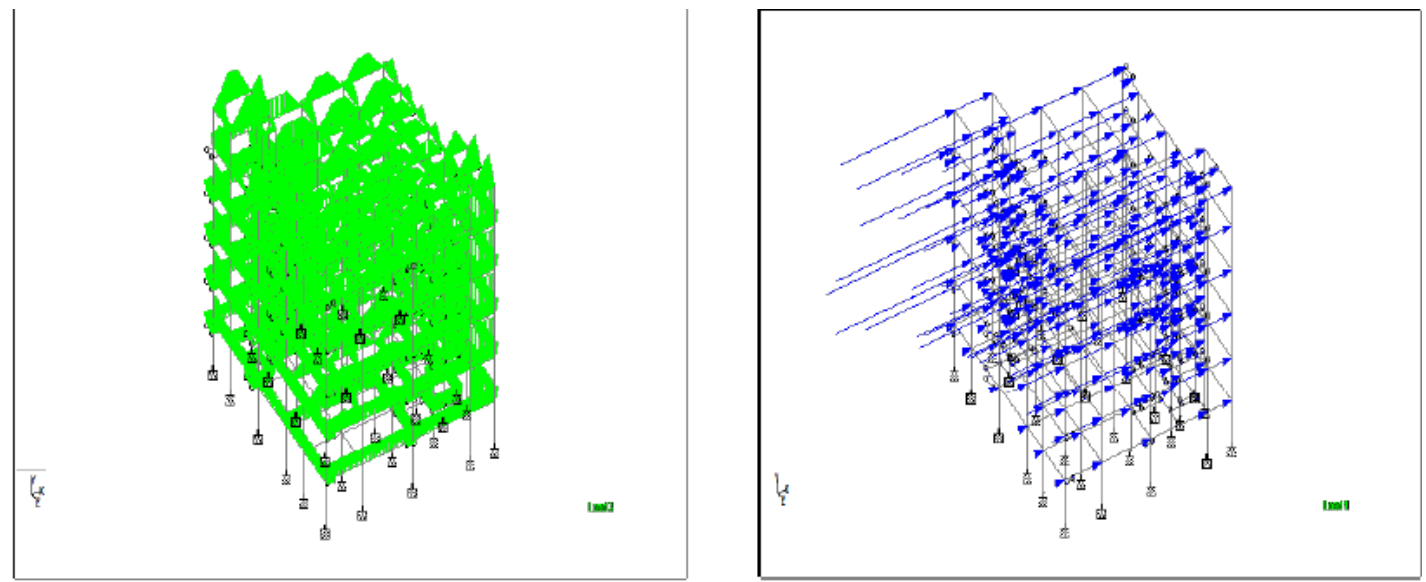

Figure 5 Staad pro model depicting vertical loads Figure 6 Staad pro depicting lateral loads

\subsection{Analysis in Staad}

Analysis in Staad pro software is implemented by applying design loads which includes vertical and lateral loads to the 3D model as shown in Figure 5 and Figure 6. Based on these load application further analysis is accomplished for design of structural components.

\section{RESULTS AND DISCUSSION}

This section presents the results of quantification of $\mathrm{CO}_{2}$ emission of slab and column components of RCC structure based on energy consumption during manufacturing of building construction material especially concrete. Table 1 to 8 represents the quantification of construction material for structural components and corresponding $\mathrm{CO}_{2}$ emission.

\subsection{Quantification of structural component (slab and Column).}

Table 1 Quantity of Typical floor for $150 \mathrm{~mm}$ thick

\begin{tabular}{|c|l|c|c|}
\hline Sr. No. & \multicolumn{1}{|c|}{ Material } & Unit & Quantity \\
\hline 1 & Concrete M25 & (cuM) & 65.69 \\
\hline & Sub Total & & 65.69 \\
\hline 2 & Steel T8 (Fe 500) & $\mathrm{kg}$ & 3526.2 \\
\hline 3 & Steel T10 (Fe 500) & $\mathrm{kg}$ & 331.59 \\
\hline 4 & Steel T12 (Fe 500) & $\mathrm{kg}$ & 66.82 \\
\hline & Subtotal & & 3924.61 \\
\hline
\end{tabular}

Table2 $\mathrm{CO}_{2}$ emission for typical floor slab of $150 \mathrm{~mm}$ thick.

\begin{tabular}{|l|l|}
\hline Specific $\mathrm{CO}_{2}$ emitted** & $4.23 \mathrm{~kg} \mathrm{CO} / \mathrm{m}^{3}$ concrete \\
\hline Total $\mathrm{CO}_{2}$ emitted** & $277.867 \mathrm{~kg} \mathrm{CO}_{2}$ \\
\hline
\end{tabular}

** $\mathrm{CO}_{2}$ emitted during manufacturing of concrete 
Harsha D. Bajpai and Dr. Tejaswini D. Nalamutt

Table 3 Quantity of Typical floor for $115 \mathrm{~mm}$ thick

\begin{tabular}{|c|l|c|c|}
\hline Sr. No. & \multicolumn{1}{|c|}{ Material } & Unit & Quantity \\
\hline 1 & Concrete M25 & (cuM) & 50.84 \\
\hline & Sub Total & & 50.84 \\
\hline 2 & Steel T8 (Fe 500) & $\mathrm{kg}$ & 3432.27 \\
\hline 3 & Steel T10 (Fe 500) & $\mathrm{kg}$ & 648.76 \\
\hline 4 & Steel T12 (Fe 500) & $\mathrm{kg}$ & 307.36 \\
\hline & Subtotal & & 4388.39 \\
\hline
\end{tabular}

Table $4 \mathrm{CO}_{2}$ emission for typical floor slab of $115 \mathrm{~mm}$

\begin{tabular}{|l|l|}
\hline Specific $\mathrm{CO}_{2}$ emitted** & $4.23 \mathrm{~kg} \mathrm{CO}_{2} / \mathrm{m}^{3}$ concrete \\
\hline Total $\mathrm{CO}_{2}$ emitted** & $215.05 \mathrm{~kg} \mathrm{CO}_{2}$ \\
\hline
\end{tabular}

** $\mathrm{CO}_{2}$ emitted during manufacturing of concrete

Percentage decrease in $\mathrm{CO}_{2}$ emission due to change in thickness of typical floor slab from $150 \mathrm{~mm}$ to $115 \mathrm{~mm}=29 \%$

Percentage increase in steel due to change in thickness of slab from $150 \mathrm{~mm}$ to $115 \mathrm{~mm}$ typical floor slab $=12 \%$

Table 5 Quantity of Columns for $\mathrm{G}+4$ structure *

\begin{tabular}{|c|l|c|c|}
\hline Sr. No. & \multicolumn{1}{|c|}{ Material } & Unit & Quantity \\
\hline 1 & Concrete M25 & (cuM) & 118.47 \\
\hline & Sub Total & & 118.47 \\
\hline 2 & Steel T10 (Fe 500) & $\mathrm{kg}$ & 10816.48 \\
\hline 3 & Steel T12 (Fe 500) & $\mathrm{kg}$ & 4513.24 \\
\hline 4 & Steel T16 (Fe 500) & $\mathrm{kg}$ & 7371.02 \\
\hline 5 & Steel T20 (Fe 500) & $\mathrm{kg}$ & 49.82 \\
\hline 6 & Steel T25 (Fe 500) & $\mathrm{kg}$ & 87.28 \\
\hline & Subtotal & & 22837.83 \\
\hline
\end{tabular}

*considering slab thickness $150 \mathrm{~mm}$

Table $6 \mathrm{CO}_{2}$ emission for entire columns of building

\begin{tabular}{|l|l|}
\hline Specific $\mathrm{CO}_{2}$ emitted** & $4.23 \mathrm{~kg} \mathrm{CO} / \mathrm{m}^{3}$ concrete \\
\hline Total $\mathrm{CO}_{2}$ emitted & $* *$ \\
\hline
\end{tabular}

** $\mathrm{CO}_{2}$ emitted during manufacturing of concrete

Table 7 Quantity of columns for G+ 4 structures*

\begin{tabular}{|c|l|c|c|}
\hline Sr. No. & \multicolumn{1}{|c|}{ Material } & Unit & Quantity \\
\hline 1 & Concrete M25 & (cuM) & 83.59 \\
\hline & Sub Total & & 83.59 \\
\hline 2 & Steel T8 (Fe 500) & $\mathrm{kg}$ & 4330.69 \\
\hline 3 & Steel T12 (Fe 500) & $\mathrm{kg}$ & 3890.38 \\
\hline 4 & Steel T16 (Fe 500) & $\mathrm{kg}$ & 4380.53 \\
\hline 5 & Steel T20 (Fe 500) & $\mathrm{kg}$ & 1935.43 \\
\hline 6 & Steel T25 (Fe 500) & $\mathrm{kg}$ & 978.37 \\
\hline & Subtotal & & 15515.4 \\
\hline
\end{tabular}

*considering slab thickness $115 \mathrm{~mm}$ 
Table $8 \mathrm{CO}_{2}$ emission for entire columns of building

\begin{tabular}{|c|c|}
\hline Specific $\mathrm{CO}_{2}$ emitted** & $4.23 \mathrm{~kg} \mathrm{CO} / \mathrm{m}^{3}$ concrete \\
\hline Total $\mathrm{CO}_{2}$ emitted $* *$ & $353.585 \mathrm{~kg} \mathrm{CO}_{2}$ \\
\hline
\end{tabular}

** $\mathrm{CO}_{2}$ emitted during manufacturing of concrete

Percentage decrease inCO $\mathrm{CO}_{2}$ emission due to change in column deign for reduced slab thickness of typical floor slab $=41 \%$

\section{CONCLUSION}

This research presents the design method of building structure for optimizing the material quantity in such a way that variation in material quantity will have direct impact on $\mathrm{CO}_{2}$ emission. The study focuses on analysis and design of G+4 RCC structure within the constraints of design codes. The analysis and design was conducted using slab and column components as variable parameter. Keeping slab thickness and column sizes as per architectural requirements, analysis and design of RCC structure is implemented. The structure is reanalyzed and designed for the change in slab thickness Following are the conclusions drawn based on the above analysis:

1) The quantification of reinforcement for the above slab design has impact on $\mathrm{CO}_{2}$ emission. Due to variation in slab thickness from $150 \mathrm{~mm}$ to $115 \mathrm{~mm}$, the reduction in quantity of $\mathrm{CO}_{2}$ emission of typical floor slab is $29 \%$.

2) The percentage decrease in quantity of $\mathrm{CO}_{2}$ emission due to change in column design for reduced slab thickness of typical floor slab is $41 \%$.

3) The increase of steel reinforcement increases the total cost of structural component, but it can have some positive effect on the global warming issues as there is reduction of concrete use.

4) Thus, increase in percentage of reinforcement for conventional structure within the constraints of structural design code, $\mathrm{CO}_{2}$ emission of the construction materials can be reduced with sustainable design approach.

5) With variation in design of structural components, a considerable amount of quantity of $\mathrm{CO}_{2}$ emission can be controlled, rather than concentrating on design and analysis of low carbon material, which requires lot of time and cost.

\section{REFEREENCES}

[1] Ariyaratne, C., Moncaster, A., Stand-alone Calculation Tools are not the Answer to embodied carbon Assessment. Energy Procedia. 2014. 62, P. 150 - 159.

[2] Azari, R., Abbasabadi, N., Embodied energy of buildings: A Review of Data, Methods, Challenges, and Research Trends. Energy \& Buildings.2018. 168, P. 225 - 235.

[3] Code of practice for design loads (Part1 to 5) - IS 875

[4] Criteria for earthquake resistant design of structures (Part1) - IS1893

[5] Code of practice for plain \& reinforced concrete - IS 456

[6] Code of practice for ductile detailing of reinforced concrete structures subjected to seismic forces - IS 13920

[7] Bras, A., Faria, P., Effectiveness of mortars composition on the embodied carbon long-term impact. Energy and Buildings, 2017. 154, P. 523 - 528.

[8] Deng, G., Xu, Y., Accounting and structure decomposition analysis of embodied carbon trade. A global perspective Energy. 2017.137, P.140 - 151. 
[9] Dixit M. K., Singh, S., Embodied energy analysis of higher education buildings using an inputoutput - based hybrid method. Energy \& Buildings. 2018. 161, P. 41-54.

[10] Dong, D., An, H., Huang, S., The transfer of embodied carbon in copper international trade: An industry chain perspective, Resources Policy. 2017. 52, P. 173 - 180.

[11] Hakkinen, T., Kuittinen, M., Ruuska, A., Jung, N., Reducing embodied carbon during the design process of buildings. Journal of Building Engineering. 2015. 4, P. 1 - 13.

[12] Hammad, A. W., Akbarnezhad, A., Oldfield, P., Optimizing embodied carbon and U-value in load bearing walls: A mathematical bi-objective mixed integer programming approach. Energy and Buildings, 2018. 174, P. $657-671$.

[13] Kumanayake, R., Luo, H., Paulusz, N., Assessment of material related embodied carbon of an office building in Sri Lanka. Energy and Buildings. 2018. 166, P. 250 - 257.

[14] Liu, B., Wang, D., Xu, Y., Liu, C., Luther, M., Embodied energy consumption of the construction industry and its international trade using multi-regional input-output analysis. Energy \& Buildings. 2018. 173, P. 489-501.

[15] Li, Q., Wen, B., Wang G., Cheng, J., Han Z., Study on calculation of carbon emission factors and embodied carbon emissions of iron-containing commodities in international trade of China. Journal of Cleaner Production. 2018. 191, P. 119 - 126.

[16] Li, X., Yang, F., Zhu, Y., Gao Y., An assessment framework for analyzing the embodied carbon impacts of residential buildings in China. Energy and Buildings. 2014. 85, P. 400 - 409.

[17] Lotteau, M., Loubet, P., Sonnemann, G., An analysis to understand how the shape of a concrete residential building influences its embodied energy and embodied carbon. Energy and Buildings. 2017. 154, P. 1-11.

[18] Lupisek, A., Vaculikova, M., Mancik, S., Hodkova, J., Ruzika, J., Design Strategies for low embodied carbon and low embodied energy buildings: principles and examples. Energy Procedia. 2015. 83, P. 147-156.

[19] Malmqvist, T., Nehasilova, M., Moncaster, A., Birgisdottir, H., Rasmussen, F., N., Wiberg, A., H., Potting, J., Design and construction. strategies for reducing embodied impacts from buildings - Case study analysis. Energy and Buildings. 2018. 166, P. 35 - 47.

[20] Pomponi, F., Moncaster, A., Scrutinizing embodied carbon in buildings: The next performance gap made manifest. Renewable and Sustainable Energy Reviews. 2018. 81, P. 2431- 2442.

[21] Pomponi, F., Moncaster, A., Wolf, C., Furthering embodied carbon assessment in practice: Results of an industry academia collaborative research project. Energy and Buildings. 2018. 167, P. $177-186$.

[22] Pu, Z., Fu, J., Zhang, C., Shao, J., Structure decomposition analysis of embodied carbon from transition economies. Technological Forecasting and Social Change. 2018. 135, P. 1-12.

[23] Rasmussen, F., N., Malmqvist, T., Moncaster, A., Wiberg, A., H., Birgidottir, H., Analyzing methodological choices in calculations of embodied energy and GHG emissions from buildings. Energy \& Buildings.2018. 158, P. 1487-1498.

[24] Rodrigues, V., Martins, A., A., Nunes, M., I., Quintas, A., Caetano, N., S., LCA of constructing an industrial building: focus on embodied carbon and energy. Energy Procedia.2018. 153, P. $420-425$.

[25] Victoria, M., F., Perera, S., Parametric embodied carbon prediction model for early stage estimating. Energy \& Buildings. 2018. 168, P. $106-119$.

[26] Vincent, J., L., Gan, M., Deng, K, T., Tse., C., M., Chan, Irene, M., C., LO., Jack, C., P., Cheng, Holistic BIM framework for sustainable low carbon design of high-rise buildings. Journal of Cleaner Production. 2018. 195, P. 1091 - 1104. 
[27] Zeng, R., Chini, A., A review of research on embodied energy of buildings using bibliometric analysis. Energy \& Buildings. 2017. 155, P. 172-184.

[28] Zhou, D., Zhou, X., Xu, Q., Wu, F., Zha, D., Regional embodied carbon emissions and their transfer characteristics in China. Structural Change and Economic Dynamics. 2018. 46, P. 180193. 